\title{
A PLACE FOR THE HUMAN FACTOR IN THE MIDST OF THE COVID-19 PANDEMIC. AS A WAY OF INTRODUCTION
}

\author{
Carmen Valero-Garcés \\ carmen.valero@uah.es \\ (1) $\mathrm{G} \mathrm{R}^{6} \mathrm{O}$
}

\section{Introduction}

Volume 8 of FITISPos $I J$, published in the spring of 2021, is marked by the COVID-19 pandemic and the transformations and consequences that have followed. The pandemic broke out at the beginning of 2020, and its end is still far off at the time of publishing these words, though the availability of vaccines and the global vaccination process have already begun.

The world is experiencing the worst economic crisis to date, dubbed the Great Lockdown by the International Monetary Fund (IMF, 2020) and only comparable to two other great crises with a capital "G" - the Great Depression (1929) and the Great Recession (2007-2014). It is a crisis that affects every aspect of life; it has completely confined us to our homes and forced governments to limit the free movement of persons at local, national and international levels. We have lived in a period of continuously de-escalating lockdown for more than one year. It is like living in a kind of induced coma in which the patient is deeply sedated to give them the opportunity to recover by consuming less energy and then woken up gently (Estefanía, 2021, p. 8). Relapses occur and progress is made, with the belief that the situation is under control, that we have learned from our past mistakes and that "this time is different" because we are smarter and better prepared. But it is hard to come out of it.

This crisis has revealed the weakness of the public sector: poor protection for citizens, the fragility of essential services such as health care, the right to education and access to a decent job and a decent home. Travel restrictions and a lack of access to public services are two key elements that affect migration. The United Nations 2030 Agenda, with the motto "Transforming our world", guarantees support to the most disadvantaged peoples and countries by promoting an action plan in which societies must commit to achieving a decent, sustainable future for all. The 2030 Agenda details a set of interconnected objectives that address the global challenges we face every day, such as poverty, inequality, climate change, environmental degradation, prosperity, peace and justice. When COVID-19 unexpectedly emerged at the beginning of 2020, everything began to revolve around the crisis, shifting from global to local but with the paradox of being more global than ever, being more informed than ever, having the world at our fingertips thanks to the internet and technology.

In the past few decades, extraordinary technological advances in machine translation (MT) and artificial intelligence (AI) have made great progress in intralinguistic communication, especially in majority languages and specialized fields. COVID-19 generated interest in technology and its use, and much progress has been made in creating Information and Communications Technology (ITC). However, such progress is not uniform, and the digital 
gap widens when dealing with languages of lesser diffusion (LLD) or migrant languages. Commonly used tools such as Google Translate, DeepL or the many open access apps on mobile devices are practically nonexistent in many of the LLD heard on our streets while we move towards a single digital marketplace in which English is the lingua franca. However, from a perspective more closely related to the 2030 Agenda's objectives, that outcome is just another technocratic utopia based on the idea that everything can be solved with technology and one language. Technology at the Service of PSIT in Crisis Situations: Experiences and Perspectives (Valero-Garcés, 2018) includes interesting points to consider; the publication is a result of the collaboration of experts from different fields with the objective of sharing and learning about resources and experiences concerning the importance of MT and computerassisted translation (CAT) tools in crisis situations.

Language issues are not usually recognized as an integral part of migratory movements or social integration, though interlinguistic communication professionals know that language is a necessary component for consolidating a stable society (Angelelli, 2015; Foulquie et al., 2018; Valero-Garcés, 2018; Wallace and Manzó, 2019). These researchers, and often professional translators and/or interpreters and trainers, understand the challenges they face in their work: a lack of time and resources for preparing future professionals, the diversity of languages and places in which interpreters are needed in LLD and a lack of training for bilinguals working as ad hoc interpreters in institutions. They also understand the effects this situation has and the role the language issue plays in it. In an article meaningfully titled "El duelo migratorio por la lengua y la cultura en el síndrome de Ulises" [Migratory grief for language and culture in Ulysses syndrome], Achotegui (2020) presents migration as a life change in which one experiences grief for several reasons. Grief for one's language is one of the most significant examples and it leads many immigrants to suffer from the immigrant syndrome of chronic and multiple stress, or Ulysses Syndrome.

The authors whose work is included in volume 8 of FITISPos IJ are researchers, professionals and translator and/or interpreter trainers who have had to face the pandemic and make significant changes in the way they teach and research. We might say that the educational response to this crisis has been almost exclusively technological and has tried to adapt to the needs of the emergency situation that arose. And the same technological response was used in many other areas of our daily lives. In some sectors, especially the most disadvantaged sectors, this situation has even provoked the feeling that the human factor of the problems we were facing was not being taken into account. And among the most disadvantaged groups, there are those who do not have access to information because they do not know the contact language; they do not have access to information distribution channels because they speak minority languages and need intermediaries to help them communicate with the public services.

Technology also interferes with training for these future intermediaries. In higher education, there is a common tendency to direct our students' attention to the use of CAT tools, delve into MT and AI and practice localization or post-editing. Fewer voices are advocating for introducing materials related to other human abilities, such as reflection, empathy, stress management, social relationships, cooperation and mediation.

In a conference held in January 2020, just before the global lockdown, O'Brien (2020) mentioned the results of a brief study carried out during a seminar about machine translation and artificial intelligence at the Summer School in Advanced Translation Technology (SATT) in 2019. O'Brien asked the course participants - mostly professional translators-what they thought should be taught to future students. Their answers included: content creation/adaptation, business skills, specializations in transcreation and localization-for example, video games - and collaborative work.

Massey (2020) also draws attention to the need to go beyond MT and CAT tools in class: "I feel that one of my jobs as an educator is to educate people to think differently, is to educate 
the translators of the future to actually take on an active role of language mediation, consultancy and risk management".

He continues:

(...) I wonder, though, whether the future might not be one closer to an intercultural mediator's role of negotiating between stakeholders who represent different cultures in various modes and media, synchronously and/ or asynchronously. We would then have to trim our teaching programs accordingly. We are training people for the markets and needs of now and the future. How can we feed the current market and anticipate future ones, melding what has been with what might be?

In an article meaningfully titled "Language service provision in the 21 st century: Challenges, opportunities and educational perspectives for translation studies" and written by authors from four countries (Italy, Switzerland, Germany and Ireland), Bernardini et al. (2020, p. 304) also point in that direction. Based on the knowledge that demand for interlinguistic and intralinguistic translation and related forms of multilingual and multimodal communication is going to increase, they believe that part of this demand could be met with the help of MT or AI. They also assert that non-specialists could satisfy part of this growing demand as a result of these engineered solutions. They conclude:

We are living in an age of continuous and fast development of new technologies, where "technology" includes entire workflow architectures. This means that the role of the language professional of the future will have to be different from what it was before: we expect that $\mathrm{s}$ / he becomes an advocate for multilingualism as a globalization tool, and possesses the know-how to manage large-scale commercial, as well as not-forprofit, global initiatives that require translation and transcreation.

Outside of the field of Translation Studies, other voices are also drawing attention to the need to go further when teaching technological skills. Thus, The Future Skills Report (Ehlers \& Kellermann, 2019) identifies three crucial aspects that must be included in higher education in the future: skills related to content development, instrumental competence and social and organizational competence. But focusing solely on the second aspect (instrumental competence), as many higher education programs are doing, means overlooking other skills, which can lead to disaster for many future professionals.

During this unusual year, all of these factors led us to dedicate volume 8 of FITISPos IJ to a topic that is not often talked about these days but that will undoubtedly fill hundreds of pages once we move past this crisis and recover from the consequences it has left behind. Thus, under the title The Human Factor in PSIT, the FITISPos group joins forces to contribute to transforming our world in line with the objectives of the UN 2030 Agenda. By combining the articles in this volume with publications and audiovisual material included in another publication with a similar title, El factor humano en el TISP. Investigación y testimonios de la primavera de 2020 / The Human Factor in TISP. Research and Testimonials of Spring 2020 (Valero-Garcés, 2020), we offer a broad vision of the complex reality of human beings and their vulnerability in the face of global disasters.

The titles of the articles included in this volume are along those lines. In alphabetical order and in English or Spanish, they represent diverse topics and research methods. In their article "Bridges and barriers in public service interpreting training: Instructing nonprofessional long-serving interpreters", Burdeus-Domingo, Gagnon, Pointurier and Yvan Leanza give an account of a research-action study that led them to design a public service interpreting (PSI) training program specifically for experienced ad hoc interpreters with no 
training. The program was adapted to the group's needs to end with a set of practical recommendations that help them overcome the difficulties discovered during the investigation.

In "Un programa de intervención para fomentar la gestión emocional en un grupo de intérpretes para los servicios públicos" [An intervention program to foster emotional management in a group of public service interpreters], Bruno and Iborra Cuéllar present the design, implementation and results of an ad hoc emotional-management course aimed at public service interpreters. The study was performed by monitoring two discussion and interview groups. As a result of the training, the authors concluded that a distinct improvement was observed in the public service interpreters' lives.

In "Re-enacting the past: The translation of performativity in oral history interviews / Recreando el pasado: la traducción de la performatividad en entrevistas de historia oral", Painca explores the connection between Translation Studies and oral history in the specific example of Romanian communism to address the topic of transcription and the power of translation when presenting history.

In "Refugee access to information in online and offline environment: Results from focus group discussions", Jiménez Andrés draws attention to the growing importance of technology in dealing with refugees' information and communication needs. The author examines information access resources in online and offline settings in refugee communities in three countries.

In "La mediación del intérprete como motor hacia la inclusión y la alianza entre naciones" [Mediation of the interpreter as a driving force for inclusion and the partnership of nations], Torrella reflects on the complex issue of the relationships between mediation and interpreting by analysing the fundamental principles included in codes of ethics and by observing interpreter-mediator behaviour in practice.

In "La práctica de la traducción literaria y la enseñanza de lenguas en entornos de integración" [The practice of literary translation in practice and language teaching in integration environments], Szymyślik presents a training program based on the translation of literary texts using English as a vehicular language to strengthen Spanish language learning in training contexts in which the participants come from minority contexts or conflict zones and are in a period of integration.

In "Interpretación en los servicios públicos en la oferta académica de grado de Argentina" [Public service interpreting in undergraduate courses in Argentina], as the title indicates, Manfredi and Lázaro Gutiérrez analyse undergraduate training in Argentina. They determine that although a course in Public Service Interpreting is not offered, some programs include basic training that allows graduates to acquire some of the skills needed to work in public services. However, they conclude that it is necessary to further train students in public service interpreting.

De Wilde, van Hest, Rillof and Van Poucke in "Observing briefly trained, non-certified interpreters at work: Risk analysis" present another training initiative implemented by the Flemish Government Integration Agency, an organization responsible for training and certifying public service interpreters. This effort is aimed at training, preparing and evaluating volunteers, some of whom already work as ad hoc interpreters or "language assistants" without certifications.

The Working Papers section includes young researchers' work based on their master's theses or doctoral dissertations.

In "El derecho a la traducción en crisis sanitarias: la COVID-19 en España, 2020 / The right to translation in health crises: COVID-19 in Spain, 2020", Llerandi approaches the problem of communicating with the foreign population in Spain at the beginning of the COVID-19 health crisis in 2020 by analysing materials available in other languages and using 
the principles of availability, accessibility, acceptability and adaptability as a conceptual framework to determine how translation is addressed.

In "An English-Spanish glossary for the study of the artificial pancreas in medical translation", as the title indicates, Jiménez Garro addresses a more specific issue to provide an example of a specialized glossary. The author emphasizes the need for this type of tool that includes standardized terms to produce accurate translations and facilitate communication between experts.

In "Corrección de textos médicos divulgativos traducidos del inglés al español en el ámbito de los servicios públicos de los Estados Unidos / Correcting the translation of informational medical texts from English to Spanish within the public services of the United States", López Blanco analyses a corpus of informational medical texts translated from English to Spanish and gathered from public organizations in the United States. The author concludes that these texts do not meet the quality standards necessary to serve the purpose for which the original texts were written - that is, to inform and educate the population.

In "Terminología e interpretación médico-sanitario en los servicios públicos en el campo de obstetricia y ginecología: propuesta de un glosario médico-sanitario español-árabe" [Medical-health care terminology and interpreting in public services in the obstetrical and gynaecological field: Designing a Spanish-Arabic medical-health care glossary], Hadji offers a further example of medical-health care terminological resource development in SpanishArabic by developing a bilingual glossary of gynaecological-obstetrical diseases, complications and disorders.

In "Análisis de la redacción de consentimientos informados en inglés y en español" [Analysis of informed consent forms in English and Spanish], using the definition of a hybrid text, María Ruiz compares a corpus of informed consent forms in Spanish and English to see if they meet the requirement of patient accessibility.

In the Interview section, we feature the words of Aimee Ansari, the current executive director of Translators Without Borders (TWB), who has worked in humanitarian contexts for several decades and collaborated with the UN and NGOs such as Oxfam and Save the Children. In the interview, she tells us about TWB's work and about the new challenges that the pandemic adds to the already fragile situation of the most vulnerable. She also talks about the projects and efforts that TWB has in progress. Aimee demonstrates her confidence in technology, collaborative work and volunteering.

The Book Review section includes comments on several books and collections of recent articles on different subjects and in different fields, which illustrate the complex circle in which PSIT is involved. The books reviewed include:

El factor humano en Traducción e Interpretación en los Servicios Públicos. Investigación y testimonios de la primavera de 2020 / The Human Factor in PSIT. Research and Testimonials of Spring 2020, edited by Carmen Valero-Garcés (2020), reviewed by Elena Pérez Estevan.

La interpretación en el contexto sanitario: Aspectos metodológicos y análisis de interacción del intérprete con el usuario [Interpreting in the health care context: Methodological aspects and analysis of the interpreter's interaction with the user], by Laura Parrilla Gómez (2019), reviewed by María de la Presentación Aguilera.

Translatum Nostrum. La traducción y la interpretación en el ámbito especializado [Translatum Nostrum. Translation and interpreting in specialized areas], edited by Carla Botella Tejera, Javier Franco Aixelá and Catalina Iliescu Gheorghiu (2020), reviewed by Maria Luengo Cabanillas. 
Traducción económica e investigación en España. Estudio bibliométrico [Economic translation and research in Spain. A bibliometric study], by Daniel Gallego Hernández (2020), reviewed by Dario Manglada.

Lengua entre dos fuegos. Intérpretes en la Guerra Civil española (1936-1939) [Language between two fires. Interpreters in the Spanish Civil War (1936-1939)], by Jesús Baigorri Jalón (2019), reviewed by Yossi Montes.

The Research Corner includes several recently defended doctoral dissertations about various topics, which confirms the growing interest in PSIT in academia. These include:

La enseñanza del lenguaje en la atención sanitaria a través de la traducción: aplicaciones didácticas de la traducción en la enseñanza de lengua extranjera de variación especializada / The teaching of language in health care through translation: Didactic applications of translation in the teaching of foreign language of specialized variation, by Blanca Aparicio Larrán, Universidad de Cádiz, 2020.

Formación y experiencia profesional como diferenciadores en la actuación de intérpretes sanitarios: un estudio de caso desde la sociología de las profesiones / Training and professional experience as differentiators in the performance of health interpreters: A case study from the sociology of professions, by Cristina Álvaro Aranda, Universidad de Alcalá, 2020 .

Investigación-acción en traducción e inmigración: la utilidad del estudio pretraductológico para el análisis crítico de la libre circulación en España y en el Reino Unido (un estudio de caso) / Action Research, Translation and Immigration: The Usefulness of a Pre-translation Analysis to Critically Analyse EU Freedom Movement Implementation in Spain and in the UK (A Case Study), by Elena Ruiz Cortés, Universidad de Granada, 2020.

Interpretación telefónica: de la teoría a la práctica y su comparación con la interpretación presencial (chino y español) / Telephone interpreting: From theory to practice and its comparison with face-to-face interpreting (Chinese and Spanish), by Jing Li, Universidad de Alcalá, 2020.

Sobre la traducción de documentos médico-legales (inglés-español): retos terminológicos, traductológicos y culturales en documentos pertenecientes a formularios de solicitud para participar en programas de intercambio académico-culturales en los Estados Unidos. Estudios de casos y aplicaciones profesionales / On the translation of medical-legal documents (English-Spanish): Terminological, translation and cultural challenges in documents belonging to application forms to participate in academic-cultural exchange programs in the United States. Case studies and professional applications, by María Rubio Gragera, Universidad de Málaga, 2020.

El derecho a la interpretación y a la traducción en el proceso penal: la Directiva 2010/64/UE / The right to interpretation and translation in criminal proceedings: Directive 2010/64/EU, by Silvia Ponce González, Universidad Católica de Valencia San Vicente Mártir, 2020.

This volume also mentions two projects related to PSIT: 
MELINCO, a project about linguistic mediation for international development, is financed by the Dirección Xeral de Relacións Exteriores e coa Unión Europea. The project's objective is to perform a diagnostic analysis of the situation of interpreting and translation in this area.

INMIGRA3-CM, a project subsidized by the Community of Madrid's Consejería de Educación e Investigación [Office for Education and Research] and the European Social Fund, studies linguistic, communicative, cultural and social factors in the migrant integration process in the Community of Madrid.

Also, several mobile applications are noted as new tools that demonstrate the importance that technology is acquiring in PSIT. Specific examples include CALD Assist app, MITA app, the AwezaMed COVID-19 app, Migrant Information Centre (MIC) app and Boostlingo Interpreter app.

We hope you enjoy reading the various sections and contributions in volume 8 of FITISPos IJ, and we hope to continue to be able to count on your collaboration in future editions. Finally, we must add that the contents of the articles and the different sections are the responsibility of their authors.

\section{References}

Achotegui, J. (2020). El duelo migratorio por la lengua y la cultura en el síndrome de Ulises. in C. Valero-Garcés (Ed.), El factor humano en el TISP. Investigación y testimonios de la primavera de 2020 / The Human Factor in TISP. Research and Testimonials of Spring 2020. Servicio de Publicaciones de la Universidad. https://www.youtube.com/watch?v=6e5QdK2rRxA\&t=61s.

Angelelli, C. V. (2015). Study on Public Service Translation in Cross-Border Healthcare. Directorate-General for Translation (European Commission). https://doi.org/10.2782/765472

Bernardini, S., Bouillon, P., Ciobanu, D., van Genabith, J., Hansen-Schirra, S., O’Brien, S., Steiner, E. \& Teich, E. (2020). Language service provision in the $21^{\text {st }}$ century: Challenges, opportunities and educational perspectives for translation studies. In $\mathrm{S}$. Noorda, P. Scott \& M. Vukasovic (Eds.), Bologna Process Beyond 2020: Fundamental values of the EHEA (pp. 297-303). Bologna, Italy: Bononia University Press. http://bolognaprocess2019.it/wp-content/uploads/2020/07/bologna-process-beyond2020.pdf

Ehlers, Ulf-D. \& Kellermann, S.A. (2019). Future Skills. The future of learning and higher education. https://nextskills.files.wordpress.com/2019/05/2019-05-17-report-vs.15.pdf

Estefanía, J. (2021). El Gran Confinamiento. El País. https://elpais.com/ideas/2021-03-05/elgran-confinamiento.html

Foulquié Rubio, A.I., Vargas-Urpi, M. \& Fernández-Pérez, M. (eds.). (2018). Panorama de la traducción y la interpretación en los servicios públicos españoles: una década de cambios, retos y oportunidades. Comares.

International Monetary Fund. (2020). World Economic Outlook, April 2020: The Great Lockdown. https://www.imf.org/en/Publications/WEO/Issues/2020/04/14/weo-april2020.

Massey, G. (2020). Language and intercultural mediation. In O'Brian, S.The Future of Translator Training in the MT Era. In Translating Europe Workshop. Machine translation and the human translator. Tampere Universities https://puolukka.uta.fi/ textmine/events/tew-tampere/OBrien Tampere Jan2020.pdf 
O'Brien, S. (2020). The Future of Translator Training in the MT Era. Translating Europe Workshop: Machine translation and the human translator, Tampere Universities. https://tuni.cloud.panopto.eu/Panopto/Pages/Viewer.aspx?id=dbb39d58-bae7-4e8f947c-acc3005ea516

The Future Skills Report (2019). https://nextskills.files.wordpress.com/2019/05/2019-05-17report-vs.15.pdf

Valero-Garcés, C. (2019). Training public service interpreters and translators: Facing challenges. Revista de Llengua i Dret, Journal of Language and Law, 71, 88-105. https://doi.org/10.2436/rld.i71.2019.3262

Valero-Garcés, C. (Ed.). (2018). Tecnología al servicio de la TISP en situaciones de crisis/ Technology at the Service of PSIT in Crisis Situations: Experiences and Perspectives. Servicio de Publicaciones de la Universidad.

Valero-Garcés, C. (Ed.). (2020). El factor humano en el TISP. Investigación y testimonios de la primavera de 2020 / The Human Factor in TISP. Research and Testimonials of Spring 2020. Servicio de Publicaciones de la Universidad.

Wallace, M. \& Monzó Nebot, E. (2019). Legal translation and interpreting in public services: Defining key issues, re-examining policies, and locating the public in public service interpreting and translation. Llengua $y$ Dret, 71, 1-13. http://dx.doi.org/10.2436/rld.i71.2019.3311

\section{How to cite this article?/ ¿Cómo citar este artículo?}

Valero-Garcés, C. (2021). A place for the human factor in the midst of the COVID-19 pandemic. As a way of introduction. FITISPos-International Journal, 8(1), 9-16. https://doi.org/10.37536/FITISPos-IJ.2021.8.1.289 